\title{
Chemical and Bioactive Characterization of Spanish and Belgian Apple Pomace for Its Potential Use as a Novel Dermocosmetic Formulation
}

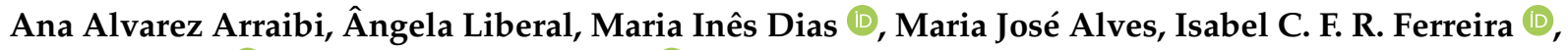 \\ Lillian Barros (1) and João C. M. Barreira *(i)
}

check for

updates

Citation: Arraibi, A.A.; Liberal, Â.; Dias, M.I.; Alves, M.J.; Ferreira, I.C.F.R.; Barros, L.; Barreira, J.C.M. Chemical and Bioactive Characterization of Spanish and Belgian Apple Pomace for Its Potential Use as a Novel Dermocosmetic Formulation. Foods 2021, 10, 1949. https://doi.org/ $10.3390 /$ foods 10081949

Academic Editor: Xanel Vecino

Received: 5 July 2021

Accepted: 16 August 2021

Published: 21 August 2021

Publisher's Note: MDPI stays neutral with regard to jurisdictional claims in published maps and institutional affiliations.

Copyright: (c) 2021 by the authors. Licensee MDPI, Basel, Switzerland. This article is an open access article distributed under the terms and conditions of the Creative Commons Attribution (CC BY) license (https:/ / creativecommons.org/licenses/by/ $4.0 /)$.
Centro de Investigação de Montanha (CIMO), Instituto Politécnico de Bragança, Campus de Santa Apolónia, 5300-253 Bragança, Portugal; ana_arraibi@hotmail.com (A.A.A.); angela_lib@hotmail.com (Â.L.); maria.ines@ipb.pt (M.I.D.); martia.alves@ipb.pt (M.J.A.); iferreira@ipb.pt (I.C.F.R.F.); lillian@ipb.pt (L.B.)

* Correspondence: jbarreira@ipb.pt

\begin{abstract}
Currently, there is a general trend towards reutilizing industrial by-products that would otherwise be discarded or considered as waste, aiming to explore them as alternative sources of valuable compounds. The apple pomace remaining from cider and apple juice industries represents a high-potential source of bioactive compounds with putative application in food or pharmaceuticalrelated products. Accordingly, the work reported herein was conducted to characterize the phenolic compounds in apple pomace from Belgium and Spain, as well as to evaluate its chemical composition and particular types of bioactivity. As a proof of concept, a new hydrogel was prepared, incorporated with the bioactive compounds and pectin extracted from apple pomace, aiming to obtain the most organic formulation possible. Independently of the extracting agent, it became evident that using lyophilization as the drying step is a better choice than thermal processes as it yielded a richer phenolic profile (fifteen individual compounds), with 5-O-caffeoylquinic acid as the major compound (66 to $114 \mathrm{mg} / 100 \mathrm{~g} \mathrm{dw}$ ) in Belgian samples. In general, the hydroethanolic extracts showed the strongest antioxidant and antimicrobial (particularly against Propionibacterium acnes: $\mathrm{MIC}=2.5 \mathrm{mg} / \mathrm{mL}$ ) activities. This result, together with the lipid nature of human skin, led it to be chosen as the extract type to be incorporated in the hydrogel. In general, apple pomace stood out as a valuable source of bioactive compounds, especially polyphenols and pectin, with good potential to be incorporated in dermal formulations.
\end{abstract}

Keywords: apple pomace; phenolic compounds; cosmeceuticals; anti-acne activity; natural hydrogel formulations

\section{Introduction}

The growing consumer consciousness about health complications associated with the use of conventional cosmetics, together with the need for a better understanding of the skin's physiology, has sponsored the demand for innovative cosmetic products based on natural substances [1]. In fact, since ancient times, the plant kingdom has been the basis of natural constituents with potential effects on protection, healing, and upkeep of the beauty of human skin through the use of herbal and seed extracts or aromatized waters [2]. Nowadays, the upward association between beauty, health, and well-being has boosted the search for so-called "natural cosmetics", the market for which, although still relatively small, is increasing much faster than the cosmetics industry in general [2-4].

Usually, conventional cosmetics cover a wide range of chemical substances, most of which are not protected by the regulatory scope of the Food and Drug Administration (FDA) or the European Medicines Agency (EMA), and only a few (e.g., parabens, phthalates, polycyclic aromatic hydrocarbons, siloxanes, and triclosan) have already been assessed for their potential harmful effects on human health [5]. In turn, herbal-based products 
hold several potentially valuable active compounds that can be useful in the handling of different skin illnesses [2,6]. Obtaining these natural substances can be favorable when natural matrices are widely available, as in the case of industrially processed fruit byproducts, which represents an ecological approach to reusing the large amounts of waste generated in this type of industry and at reduced prices [7].

Apple (Malus sp., Rosaceae) is one of the most popular and highly consumed fruits worldwide, being known for its valuable effects in preventing cardiovascular and respiratory diseases, diabetes, obesity, and cancer [7]. Most harvested apples are processed and converted into juice and cider, an industrial activity that produces a large sum of underutilized by-products. The apple pomace that remains after juice extraction and cider production (circa $\frac{1}{4}$ of the fresh fruit weight) consists of leftover flesh, peels, seeds, and stems of different apple varieties [8,9]. Despite being naturally considered as waste, these residual materials are rich in bioactive compounds, particularly polyphenols, fibers, vitamins, and carotenoids [10]. Although some polyphenols are transferred to juice during the processing step, most remain in apple peel and, consequently, in apple pomace. Phytochemicals and active compounds present in the latter also include dietary fiber, pectin, triterpenoids, and volatile compounds. Pectin is known for its application as a gelling agent, being employed in different industrial sectors (food, pharmaceutics, and cosmetics), playing also several biological and physiological functions in human organisms. These functional properties make pectin a promising nutraceutical with low toxicity and production cost [11-13].

Even though apple pomace by-products present a high potential in several sectors, these are still far from being used at full potential, especially in the food and pharmaceutical industries $[9,14]$. Its bioactive compounds can be exploited as cosmeceuticals which, in addition to their inherent application, can be used to promote skin health. The search for these types of cosmetic products presents itself as a challenge in the current cosmetic industry. Among the polyphenols identified in apple pomace, phloretin and phlorizin seem to have the greatest potential as natural alternatives to synthetic antimicrobials and antioxidants [15]. In addition to its anti-aging effects, identified by Park et al. [16], an in vitro study also demonstrated the inhibitory capacity of a polyphenolic apple extract on the fat type produced in sebaceous cells, suggesting that these secondary metabolites might regulate sebum production, relieve skin diseases such as acne [17], and reduce dermal inflammation, a capacity attributed to their inherent antioxidant assets [18].

Thus, the present study intends to explore and describe the phenolic composition and bioactivity (antioxidant and antimicrobial) of apple pomace to validate its potential as an innovative source of cosmeceuticals to be included in new natural formulations, adding value to this material currently considered as industrial bio-waste. In addition to this main purpose, an additional preliminary characterization of its proximate composition was also performed to assess potential food applications. Moreover, instead of using typical commercial gelling agents (such as carbopol 940), we intended to isolate pectin from apple pomace by hot acid extraction, thus using this by-product considering two distinct aims.

\section{Material and Methods}

\subsection{Standards and Reagents}

HPLC-grade acetonitrile was purchased from Fisher Scientific (Lisbon, Portugal). Standards of gallic acid and catechin were acquired from Sigma (St. Louis, MO, USA), 2,2diphenyl-1-picrylhydrazyl (DPPH) and $\beta$-carotene from Alfa Aesar (Ward Hill, MA, USA), and phenolic compounds from Extrasynthese (Genay, France). Muller-Hinton broth (MHB), tryptic soy broth (TSB), blood agar with 7\% sheep blood, and MacConkey agar plates were obtained from Biomerieux (Marcyl'Etoile, France). The dye $p$-iodonitrotetrazolium chloride (used as a microbial growth indicator) was provided by Sigma-Aldrich (St. Louis, MO, USA), while propanediol, citric acid, and triethanolamine were from Sigma (St. Louis, MO, USA). Ethanol and all other solvents and chemicals were of analytical grade and provided 
by Merck (Darmstadt, Germany). A Milli-Q water purification system (TGI Pure Water Systems, Greenville, SC, USA) was used to treat water.

\subsection{Samples}

Apple pomace samples were kindly supplied by Corporación Hijos de la Rivera S.L. (La Coruña, Spain) and Tuinsappen Lombarts Calville (Ypres, Belgium). The pomaces were obtained from a mixture of apple varieties harvested during the 2017 season. Samples from Spain consisted mainly of a mixture of Rabosa, Pero, Príncipe, Verdeña, Perezosa, and De la Riega varieties. The Spanish pomace samples were immediately frozen after the pressing step in the beginning of November and kept at $-80{ }^{\circ} \mathrm{C}$ until lyophilization. Samples obtained from the Belgian company consisted of approximately 25 different regional "old varieties", such as Jacques Lebel, Keuleman, Lombarts Calville, Reinette de Flandre, Quastresdouble, Collapuis, and President van Dievoet. In turn, the Belgian pomace samples were dried at $50{ }^{\circ} \mathrm{C}$ immediately after the pressing step in December 2017, and two different pomace types were provided: one from cider production and the other from juice production, where the varieties were sweeter.

Both samples were then ground into a fine powder and stored protected from light and humidity until further analysis.

\subsection{Extract Preparation}

Decoction, hydromethanolic (methanol:water, 80:20, v/v), hydroethanolic (ethanol: water, 80:20,v/v), and ethanolic extracts from both apple pomace samples were prepared, and the extracts were used for determination of phenolic compounds and biological activities. Briefly, for decoction extracts, each sample ( 1 g) was kept (5 min) in ebullition in $100 \mathrm{~mL}$ of distilled water and filtered through Whatman filter paper No 4 . The obtained decoctions were freeze-dried (FreeZone 4.5, Labconco, Kansas City, MO, USA) [19]. The remaining extracts were prepared by macerating the dry material with each corresponding solvent [20]. Briefly, $1 \mathrm{~g}$ of each sample was extracted $\left(1 \mathrm{~h}, 25^{\circ} \mathrm{C}, 150 \mathrm{rpm}\right)$ twice with $30 \mathrm{~mL}$ of each solvent and filtered through Whatman No. 4 paper. The alcohol solvents were removed using a rotary evaporator (Büchi R-210, Flawil, Switzerland); the remaining water was lyophilized (FreeZone 4.5 model 7750031, Labconco, Kansas City, MO, USA).

\subsection{Chemical Composition}

\subsubsection{Proximate Composition and Energetic Value}

Proximate composition: crude protein (macro-Kjeldahl method, $\mathrm{N} \times 6.25$, model Pro-Nitro-A, JP Selecta, Barcelona), crude fat (Soxhlet extraction, petroleum ether, $7 \mathrm{~h}$ ), and ash (incineration, $550 \pm 5^{\circ} \mathrm{C}$ ) were determined and expressed in $\mathrm{g} / 100 \mathrm{~g}$ dry sample [21]. Total carbohydrates content was calculated by difference:

$$
\text { Total carbohydrates }(\mathrm{g} / 100 \mathrm{~g})=100-\left(\mathrm{g}_{\mathrm{fat}}+\mathrm{g}_{\mathrm{ash}}+\mathrm{g}_{\text {proteins }}\right)
$$

The corresponding energy was calculated according to the Atwater system:

$$
\text { Energy }(\mathrm{kcal} / 100 \mathrm{~g})=4 \times(\mathrm{g} \text { proteins }+\mathrm{g} \text { carbohydrates })+9 \times(\mathrm{g} \text { fat })
$$

\subsubsection{Sugars}

The method employed by Barros et al. [20] was followed. Sugars were identified using high-performance liquid chromatography with a refraction index detector (HPLC-RI; Knauer, Smartline 1000 and Smartline 2300 systems, respectively) under the previously optimized chromatographic conditions. The identification step was performed by comparing the relative retention time (Rt) of the peaks with authentic standards. Quantification ( $\mathrm{g} / 100 \mathrm{~g} \mathrm{dw}$ ) was based on the internal standard method (IS: melezitose, Sigma-Aldrich, St. Louis, MO, USA) using the Clarity Software (Data Apex, Prague, Czech Republic). 


\subsubsection{Phenolic Compounds}

The phenolic profile was evaluated (Dionex Ultimate 3000 UPLC, Thermo Scientific, San Jose, CA, USA) after redissolving each lyophilized extract in ethanol/water (80:20; $v / v)$ to a final concentration of $10 \mathrm{mg} / \mathrm{mL}$ (for decoctions and hydromethanolic extracts) or $20 \mathrm{mg} / \mathrm{mL}$ (for hydroethanolic and ethanolic extracts). A DAD detector (280 and $370 \mathrm{~nm}$ as the preferred wavelengths) coupled to an electrospray ionization mass detector (LC-DADESI/MSn) was used. The selected column was a Waters Spherisorb S3 ODS-2 C18 (3 $\mu \mathrm{m}$, $4.6 \times 150 \mathrm{~mm}$, Waters, Milford, MA, USA) functioning at $35^{\circ} \mathrm{C}$. Compounds were eluted with a gradient mixture of $0.1 \%$ formic acid in water and acetonitrile. MS analysis was performed in negative mode (Linear Ion Trap LTQ XL mass spectrometer, ThermoFinnigan, San Jose, CA, USA) using an electrospray ionization source (ESI). Phenolic compounds were identified based on their chromatographic behavior, spectra, and UV-Vis mass, either by comparison with authentic standards or available data from similar studies using the Xcalibur ${ }^{\circledR}$ software (ThermoFinnigan, San Jose, CA, USA). Each compound concentration ( $\mathrm{mg} / \mathrm{g}$ of lyophilized extract) was quantified through calibration curves drawn from the UV signal of the corresponding (or most similar) standard compound [22].

\subsection{Bioactive Properties}

\subsubsection{Antioxidant Activity}

The antioxidant activity of apple pomace extracts was assessed by the mean of three assays: (i) DPPH radical scavenging activity (ELX800 microplate reader, Bio-Tek Instruments, Inc.; Winooski, VT, USA) was calculated as the percentage of DPPH discoloration by comparing the absorbance at $515 \mathrm{~nm}$ :

$$
\left[\left(\mathrm{A}_{\mathrm{DPPH}}-\mathrm{AS}\right) / \mathrm{A}_{\mathrm{DPPH}}\right] \times 100
$$

(ii) reducing power was evaluated as the capacity to convert $\mathrm{Fe}^{3+}$ into $\mathrm{Fe}^{2+}$ by measuring the absorbance at $690 \mathrm{~nm}$; (iii) inhibition of $\beta$-carotene bleaching was evaluated through the $\beta$-carotene/linoleate assay, in which the neutralization of linoleate free radicals avoids $\beta$ carotene bleaching, indicated through the percentages obtained with the following formula:

$$
\text { ( } \beta \text {-carotene absorbance after } 2 \mathrm{~h} \text { of assay/initial absorbance) } \times 100
$$

The results were expressed in $\mathrm{EC}_{50}$ values (sample concentration providing $50 \%$ of antioxidant activity or 0.5 of absorbance in the reducing power assay) [23].

\subsubsection{Antibacterial Activity}

The microdilution method together with the rapid colorimetric $p$-iodonitrotetrazolium chloride (INT) assay was used. Stock solutions from each hydroalcoholic and ethanolic extract were prepared by dissolving $100 \mathrm{mg}$ in $5 \mathrm{~mL}$ of TSB medium with $5 \%$ DMSO. The assay was performed with ATCC cultures (11827, Liofilchem, Italy)—Propionibacterium acnes (Gram-negative) — or with clinical isolates from patients hospitalized in the Local Health Unit of Bragança or the Central Hospital of Trás-os-Montes and Alto-Douro (Vila Real) Staphylococcus aureus (Gram-positive) isolated from wound exudate, Proteus mirabilis (Gramnegative) from urine, and Pseudomonas aeruginosa (Gram-negative) from expectoration. The selected bacterial strains were used to screen the antimicrobial activity of the extracts in the study since they are typically found in human skin, with a special focus on P. acnes, linked to the skin disorder acne vulgaris. The activity indicator was presented as the minimal inhibition concentration (MIC). Ampicillin, methicillin, and streptomycin (for P. acnes) were used as positive controls.

\subsection{Pectin Extraction}

Pectin was obtained by hot acid extraction, following a previously established procedure [24], with minor modifications. In brief, $\sim 50 \mathrm{~g}$ of frozen apple pomace was mixed with $200 \mathrm{~mL}$ of distilled water and heated to $90{ }^{\circ} \mathrm{C}$ under continuous stirring (350 rpm). 
Hydrochloric acid was added to decrease the $\mathrm{pH}$ to 1.5 or 3 . The slurry was cooled using an ice bath for $30 \mathrm{~min}$ and the liquid portion was separated by centrifugation at $6000 \mathrm{rpm}$ for $30 \mathrm{~min}$ at $15^{\circ} \mathrm{C}$. The supernatants were then vacuum filtered over a Buchner funnel with Whatman No. 4 filter paper. The remaining solids were centrifuged and filtered under the same conditions and the supernatants were combined, with a final $\mathrm{pH}$ readjustment to 3.5 with $1 \mathrm{M}$ sodium hydroxide. The extract was then mixed with an equal volume of ethanol and stirred for $10 \mathrm{~min}$ at room temperature. The precipitate was separated by centrifugation under the same conditions mentioned above, dispersed in $500 \mathrm{~mL}$ of $70 \%$ ethanol, and stirred (10 $\mathrm{min}, 250 \mathrm{rpm}$, room temperature). The extracted pectin was freeze-dried (Labconco FreeZone 4.5 , Kansas City, MO, USA) at $-50^{\circ} \mathrm{C}$ and $0.22 \mathrm{mbar}$ for approximately $60 \mathrm{~h}$. The yield was gravimetrically determined according to the following equation:

$$
\% \text { pectin }=m_{\text {pectin }} / m_{\text {app }} \times 100
$$

where $m_{\text {pectin }}$ is the mass of pectin obtained and $m_{\text {app }}$ is the total mass of frozen apple pomace used in the extraction.

\subsection{Dermocosmetic Gel Formulation}

For the dermocosmetic gel formulation, pectin was redissolved in water by the direct addition method [25] and citric acid (300 mg) was added to create a more acidic environment and facilitate pectin dissolution. The solution was heated $\left(60-100^{\circ} \mathrm{C}\right)$ under vigorous agitation for $20 \mathrm{~min}$ until complete dissolution. Then, $175 \mathrm{mg}$ of the phenolic extract was dissolved in $500 \mu \mathrm{L}$ of distilled water and $1 \mathrm{~g}$ of propylene glycol was used as a humectant agent. The resulting extract was added to the pectin gel and stirred at room temperature to obtain a homogeneous distribution of the phenolic extract. The $\mathrm{pH}$ was adjusted by adding $500 \mathrm{mg}$ of triethanolamine, obtaining a final $\mathrm{pH}$ of 5.69. Other gels were prepared using $350 \mathrm{mg}$ of phenolic extract and, in this case, citric acid was not added. A blank gel formulation (without phenolic extract) was also prepared for posterior comparison of bioactivities.

\subsection{Bioactivity of the Dermocosmetic Gel}

Antioxidant and antimicrobial assays were performed for the different hydrogel formulations as previously described for the extracts (Section 2.4). In the DPPH antioxidant assay, the reaction was performed in a vial and not directly in the wells as usual since pectin precipitates at the bottom of the well, clogging the passage of light and consequently obstructing determination of the absorbance.

\subsection{Statistical Analysis}

The analytical tests were performed in triplicate, and the corresponding results were expressed as mean values \pm SD. Together with a homoscedasticity verification, the variance was compared using Tukey's test (homoscedastic distributions) or Tamhane's T2 test (heteroscedastic distributions). In cases with only two different available results (e.g., quercetin-O-hexoside II in Belgian apple pomace), Student's $t$-test was applied instead using the same $\alpha=0.05$. The Shapiro-Wilk test and the Levene test were previously performed to verify the normal distribution of results and the homogeneity of variances. IBM SPSS Statistics for Windows, version 22.0, was used (IBM Corp., Armonk, NY, USA).

\section{Results and Discussion}

\subsection{Proximate Composition}

The results achieved for macronutrients in apple pomace samples are presented in Table 1. Since the samples provided by Tuinsappen Lombarts Calville (Belgium) were already dried by the company itself, the moisture content was not assessed. With respect to the samples provided by Corporación Hijos de la Rivera S.L. (Spain), they still retained a considerable water content $(75.3 \mathrm{~g} / 100 \mathrm{~g} \mathrm{fw})$, similar to that reported in a previous analytical study (71.5 to $78.6 \mathrm{~g} / 100 \mathrm{~g} \mathrm{fw}$ ) performed by Gullón et al. [7], who investi- 
gated the average compositional values of nine apple pomace samples from different varieties. Carbohydrates were the major macronutrient, with values ranging from 93.0 to $94.2 \mathrm{~g} / 100 \mathrm{~g} \mathrm{dw}$ for the Spanish and Belgian (cider) samples, respectively. Moreover, according to the results attained for soluble sugars, carbohydrates were mainly present as individual sugars, particularly fructose and glucose and a small percentage of sucrose. The apple pomace from Belgian apple cultivars used in juice extraction presented the highest fructose content ( $55 \mathrm{~g} / 100 \mathrm{~g} \mathrm{dw})$, which, in turn, was detected in its lowest quantity in the same Belgian cultivars used for cider production $(42 \mathrm{~g} / 100 \mathrm{~g} \mathrm{dw})$. Glucose and sucrose were both found in the highest amounts in the apple pomace from Spanish apple cultivars (26 and $7.4 \mathrm{~g} / 100 \mathrm{~g} \mathrm{dw}$, respectively), thus presenting the highest sugar content among the studied samples. In both cases, the sugar content was similar to that detected in previous studies [7]. Since carbohydrates quantities detected among the samples under study were very alike, and those of sugars were not, it can be hypothesized that apple pomace from cider production with Belgian cultivars may have a higher percentage of total of fiber. Overall, the studied samples presented statistically significant differences $(p<0.05)$ regarding proteins, fat, and ash content, although the proximate profiles were very similar to those characterized in industrial apple pomace from a different company [26]. In general, apple pomace revealed an interesting nutritional potential, promoting its use in food products and offering a value-added alternative for other industries.

Table 1. Proximate composition of the studied apple pomace samples (mean $\pm \mathrm{SD}$ ).

\begin{tabular}{ccccc}
\hline & Spanish & Belgian (Cider) & Belgian (Juice) & $\begin{array}{c}\text { ANOVA } \\
(\boldsymbol{p} \text {-Value) }(\boldsymbol{n}=\mathbf{5 4})\end{array}$ \\
\hline Moisture $(\mathrm{g} / 100 \mathrm{~g} \mathrm{fw})$ & $75.3 \pm 0.4$ & $*$ & $*$ & - \\
Fat $(\mathrm{g} / 100 \mathrm{~g} \mathrm{dw})$ & $1.9 \pm 0.1^{\mathrm{a}}$ & $1.6 \pm 0.1^{\mathrm{b}}$ & $1.0 \pm 0.1^{\mathrm{c}}$ & $<0.001$ \\
Proteins $(\mathrm{g} / 100 \mathrm{~g} \mathrm{dw})$ & $3.3 \pm 0.1^{\mathrm{b}}$ & $2.8 \pm 0.1^{\mathrm{c}}$ & $4.0 \pm 0.2^{\mathrm{a}}$ & $<0.001$ \\
Ash $(\mathrm{g} / 100 \mathrm{~g} \mathrm{dw})$ & $1.7 \pm 0.2^{\mathrm{b}}$ & $1.4 \pm 0.1^{\mathrm{c}}$ & $1.9 \pm 0.2^{\mathrm{a}}$ & $<0.001$ \\
Carbohydrates $(\mathrm{g} / 100 \mathrm{~g} \mathrm{dw})$ & $93.0 \pm 0.2^{\mathrm{b}}$ & $94.2^{\mathrm{b}} \pm 0.2^{\mathrm{a}}$ & $93.1 \pm 0.3^{\mathrm{b}}$ & $<0.001$ \\
Energy value $(\mathrm{kcal} / 100 \mathrm{~g} \mathrm{dw})$ & $351 \pm 12^{\mathrm{a}}$ & $291 \pm 4^{\mathrm{c}}$ & $329 \pm 7^{\mathrm{b}}$ & $<0.001$ \\
\hline Fructose $(\mathrm{g} / 100 \mathrm{~g} \mathrm{dw})$ & $46 \pm 1^{\mathrm{b}}$ & $42 \pm 1^{\mathrm{c}}$ & $55 \pm 1^{\mathrm{a}}$ & $<0.001$ \\
Glucose $(\mathrm{g} / 100 \mathrm{~g} \mathrm{dw})$ & $26 \pm 2^{\mathrm{a}}$ & $23 \pm 1^{\mathrm{b}}$ & $20 \pm 1^{\mathrm{c}}$ & $<0.001$ \\
Sucrose $(\mathrm{g} / 100 \mathrm{~g} \mathrm{dw})$ & $7.4 \pm 0.2^{\mathrm{a}}$ & $1.7 \pm 0.1^{\mathrm{b}}$ & $1.8 \pm 0.1^{\mathrm{b}}$ & $<0.001$ \\
\hline
\end{tabular}

Different letters across each line denote values with statistically significant differences $(p<0.05)$. The calibration curve equations were as follows: fructose $\left(\mathrm{y}=1.04 \mathrm{x} ; \mathrm{R}^{2}=0.999 ; \mathrm{LOD}=0.05 \mathrm{mg} / \mathrm{mL} ; \mathrm{LOQ}=0.18 \mathrm{mg} / \mathrm{mL}\right) ;$ glucose $\left(\mathrm{y}=0.935 \mathrm{x} ; \mathrm{R}^{2}=0.999 ; \mathrm{LOD}=0.08 \mathrm{mg} / \mathrm{mL}\right.$; $\mathrm{LOQ}=0.25 \mathrm{mg} / \mathrm{mL})$; sucrose $\left(\mathrm{y}=1.17675 \mathrm{x} ; \mathrm{R}^{2}=0.997 ; \mathrm{LOD}=0.06 \mathrm{mg} / \mathrm{mL} ; \mathrm{LOQ}=0.30 \mathrm{mg} / \mathrm{mL}\right)$. Energy values were calculated as follows:

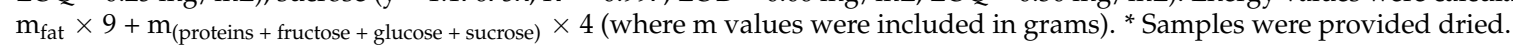

\subsection{Phenolic Compounds}

In order to investigate the effect of the extraction step on phenolic compounds' yield and bioactivity performance, four different extracts of each apple pomace sample were prepared by maceration, using the same solid:liquid ratio (1:30) with different solventsnamely water, ethanol, ethanol:water $(80: 20, v / v)$, and methanol:water $(80: 20, v / v)$-and the results are presented in Table 2. Extraction yields with different solvents show statistically significant differences $(p<0.05)$ between samples, which might, in part, be explained by the simultaneous extraction of soluble sugars (e.g., Spanish apple pomace, which contained the highest soluble sugar amount, reached the maximum yield when extracted with water, pure or in mixture). Likewise, each apple pomace sample showed a different extraction yield according to the selected solvent, with statistically significant differences between them. This result might, once again, be related to the soluble sugar content, since Spanish apple pomace reached the maximum yield in all cases where water was used as the extraction solvent. 
Table 2. Phenolic compounds' extraction yields from the studied apple pomace decoction, ethanolic, hydromethanolic, and hydroethanolic extracts (relative \%; mean $\pm \mathrm{SD}$ ).

\begin{tabular}{|c|c|c|c|c|c|}
\hline & $\mathrm{H}_{2} \mathrm{O}$ & EtOH & $\begin{array}{l}\text { EtOH: } \mathrm{H}_{2} \mathrm{O} \\
(80: 20, v / v)\end{array}$ & $\begin{array}{c}\mathrm{MeOH}: \mathrm{H}_{2} \mathrm{O} \\
(80: 20, v / v)\end{array}$ & $\begin{array}{c}\text { ANOVA } \\
(p \text {-Value })(n=54)\end{array}$ \\
\hline Spanish & $52 \pm 2^{\text {aA }}$ & $44 \pm 1 \mathrm{bC}$ & $47 \pm 3^{\mathrm{bB}}$ & $47 \pm 1^{\mathrm{bB}}$ & $<0.001$ \\
\hline Belgian (cider) & $28 \pm 1^{\mathrm{cB}}$ & $41 \pm 1^{\mathrm{bA}}$ & $41 \pm 3^{\mathrm{cA}}$ & $40 \pm 1^{\mathrm{cA}}$ & $<0.001$ \\
\hline Belgian (juice) & $37 \pm 2^{b C}$ & $65 \pm 8^{\text {aA }}$ & $52 \pm 2^{a B}$ & $50 \pm 1^{\mathrm{aB}}$ & $<0.001$ \\
\hline ANOVA ( $p$-value) $(n=54)$ & $<0.001$ & $<0.001$ & $<0.001$ & $<0.001$ & - \\
\hline
\end{tabular}

Different lowercase letters and uppercase letters across each line denote values with statistically significant differences $(p<0.05)$ for at least one apple pomace type or for at least one solvent, respectively.

Besides extraction yield, the phenolic composition of each of the prepared extracts was investigated. The tentative identification of the phenolic compounds found in the studied apple pomace extracts as well as the retention time (Rt), maximum absorbance $\left(\lambda_{\max }\right)$, pseudomolecular ion $\left([\mathrm{M}-\mathrm{H}]^{-}\right)$, and the main ion fragments $\left(\mathrm{MS}^{2}\right)$ of each phenolic compound and their individual concentrations are presented in Tables 3 and 4. Regarding the apple pomace samples provided by the Spanish company (Table 3), fifteen different phenolic compounds were identified: three phenolic acids (peaks 1 to 3), four flavan-3ols (peaks 4 to 7), five flavonoids (peaks 9-11, 13, and 14), and three di-hydrochalcones (peaks 8,12 , and 15). Peak $\mathbf{1}\left([\mathrm{M}-\mathrm{H}]^{-}\right.$at $m / z$ 341) was tentatively identified as caffeic acid hexoside based on its pseudomolecular ion, while peak 2 was easily distinguished by its base peak at $\mathrm{m} / \mathrm{z} 173$ [quinic acid- $-\mathrm{H}_{-} \mathrm{H}_{2} \mathrm{O}$ ] ${ }^{-}$, which, according to the fragmentation pattern described by [27], allowed its tentative identification as 4-O-caffeoylquinic acid. Then, peaks $3,5,9,10$, and 13 were tentatively identified as 5-O-caffeoylquinic acid, epicatechin, quercetin-3-O-rutinoside, quercetin-3-O-glucoside, and isorhamnetin-3-O-rutinoside, respectively, by comparison with authentic standards, as well as by their MS fragmentation patterns, retention times, and UV-Vis characteristics. Peaks 4, 6, and 7 represent proanthocyanidin oligomers of the procyanidin class (i.e., consisting of catechin and/or epicatechin units). Peak 4 presented a pseudomolecular ion $[\mathrm{M}-\mathrm{H}]^{-}$at $m / z 577$ and $\mathrm{MS}^{2}$ fragmentation patterns coherent with B-type (epi)catechin dimers (i.e., (epi)catechin units with $\mathrm{C} 4-\mathrm{C} 8$ or $\mathrm{C} 4-\mathrm{C} 6$ interflavan linkages). Characteristic product ions were observed at $m / z 451(-126 \mathrm{mu}), 425(-152 \mathrm{mu})$, and $407(-152-18 \mathrm{mu})$, attributable to the heterocyclic ring fissions (HRF), retro-Diels-Alder (RDA), and further loss of water from an (epi)catechin unit, and at $\mathrm{m} / \mathrm{z} 289$, which is associated with the fragment corresponding to the (epi)catechin unit. Similarly, peak $6\left([\mathrm{M}-\mathrm{H}]^{-}\right.$at $m / z$ 865) and peak $7\left([\mathrm{M}-\mathrm{H}]^{-}\right.$at $\mathrm{m} / \mathrm{z}$ 1153) can be assigned as B-type (epi)catechin trimers and tetramers, respectively. In all cases, the fragmentation patterns are coherent with those expected for these types of compounds, such as those observed for procyanidin dimers but with additional fragments from the alternative cleavages of different interflavan bonds. Peaks $11\left([\mathrm{M}-\mathrm{H}]^{-}\right.$at $\left.\mathrm{m} / \mathrm{z} 463\right)$ and $\mathbf{1 3}\left([\mathrm{M}-\mathrm{H}]^{-}\right.$at $\left.m / z 433\right)$ were identified as quercetin derivatives, both presenting $\mathrm{MS}^{2}$ fragments corresponding to distinct losses of hexosyl $(-162 \mathrm{mu})$ and pentosyl $(-132 \mathrm{mu})$ moieties and an elution order coherent with the type of substituent sugars according to their expected polarity, although the position and nature of the sugar moieties could not be identified since their retention times did not correspond to any of the available standards. Consequently, the referred compounds were tentatively identified as quercetin- $O$-hexoside and quercetin-O-pentoside, respectively. Peaks $8\left([\mathrm{M}-\mathrm{H}]^{-}\right.$at $\left.m / z 583\right), 12\left([\mathrm{M}-\mathrm{H}]^{-}\right.$at $\mathrm{m} / \mathrm{z} 567)$, and $15\left([\mathrm{M}-\mathrm{H}]^{-}\right.$at $\left.\mathrm{m} / \mathrm{z} 435\right)$ were tentatively identified as hydroxyphloretin-2'-Oxylosyl-glucoside, phloretin-2'-O-xyloglucoside, and phlorizin (phloretin-2'-O-glucoside), respectively, chalcones commonly present in apple. These compounds' identification was performed considering previous studies describing the phenolic profile of apple pomace extracts [9]. 


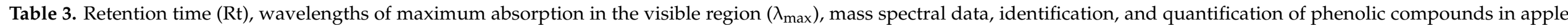
pomace from Corporación Hijos de la Rivera S.L. (Spain).

\begin{tabular}{|c|c|c|c|c|c|c|c|c|c|c|}
\hline \multirow{2}{*}{ Peak } & \multirow{2}{*}{ Rt (min) } & \multirow{2}{*}{$\lambda_{\max }(\mathrm{nm})$} & \multirow{2}{*}{$\begin{array}{l}\text { Molecular Ion } \\
(\mathrm{m} / \mathrm{z})\end{array}$} & \multirow[b]{2}{*}{$\operatorname{MS}^{2}(m / z)$} & \multirow{2}{*}{ Tentative Identification } & \multicolumn{4}{|c|}{ Quantification (mg/100 g dw) } & \multirow{2}{*}{$\begin{array}{c}\text { ANOVA } \\
(p \text {-Value })(n=72)\end{array}$} \\
\hline & & & & & & EtOH & $\mathrm{H}_{2} \mathrm{O}$ & MEOH: $\mathrm{H}_{2} \mathrm{O}$ & EtOH: $\mathrm{H}_{2} \mathrm{O}$ & \\
\hline 1 & 4.87 & 324 & 341 & $179(100)$ & Caffeic acid hexoside & $\operatorname{tr}$ & $\operatorname{tr}$ & $\operatorname{tr}$ & $\operatorname{tr}$ & - \\
\hline 2 & 6.67 & 322 & 353 & $\begin{array}{c}\text { 191(12), 179(1), 173(100), } \\
161(1), 135(2)\end{array}$ & 4-O-Caffeoylquinic acid & $14 \pm 2^{c}$ & $20 \pm 1^{a}$ & $18 \pm 2^{b}$ & $11 \pm 2^{d}$ & $<0.001$ \\
\hline 3 & 7.24 & 327 & 353 & $\begin{array}{c}191(100), 179(6), 173(2) \\
161(1), 135(1)\end{array}$ & 5-O-Caffeoylquinic acid & $114 \pm 20^{\mathrm{a}}$ & $69 \pm 6^{b}$ & $108 \pm 16^{\mathrm{a}}$ & $66 \pm 1^{b}$ & $<0.001$ \\
\hline 4 & 8.02 & 281 & 577 & $\begin{array}{c}451(24), 425(100), 407(21) \\
289(12)\end{array}$ & B-type (epi)catechin dimer & $18 \pm 4^{b}$ & $16 \pm 1^{b}$ & $29 \pm 6^{a}$ & $19 \pm 4^{b}$ & $<0.001$ \\
\hline 5 & 9.82 & 281 & 289 & $\begin{array}{c}\text { 245(100), } 203(5), 187(1) \\
161(2), 137(2)\end{array}$ & Epicatechin & $31 \pm 1$ & $\operatorname{tr}$ & $12 \pm 1$ & $\operatorname{tr}$ & $<0.001 *$ \\
\hline 6 & 11.39 & 280 & 865 & $\begin{array}{c}739(74), 713(44), 695(100) \\
577(64), 575(37), 425(10), \\
407(9), 289(8), 287(7)\end{array}$ & B-type (epi)catechin trimer & $10 \pm 2^{b}$ & $10 \pm 1^{b}$ & $17 \pm 1^{\mathrm{a}}$ & $7 \pm 2^{c}$ & $<0.001$ \\
\hline 7 & 12.54 & 280 & 1153 & $\begin{array}{l}865(19), 863(18), 577(6) \\
575(11), 289(3), 287(4)\end{array}$ & B-type (epi)catechin tetramer & $2.4 \pm 0.2^{\mathrm{d}}$ & $4.0 \pm 0.1^{\mathrm{c}}$ & $15 \pm 2^{a}$ & $7 \pm 2^{b}$ & $<0.001$ \\
\hline 8 & 16.13 & 282 & 583 & $289(100)$ & $\begin{array}{l}\text { 3-Hydroxyphloretin-2'-O- } \\
\text { xylosyl-glucoside }\end{array}$ & $4.5 \pm 0.5^{b}$ & $1.9 \pm 0.4^{\mathrm{d}}$ & $3.6 \pm 0.4^{c}$ & $5.6 \pm 0.5^{\mathrm{a}}$ & $<0.001$ \\
\hline 9 & 17.95 & 353 & 609 & $301(100)$ & Quercetin-3-O-rutinoside & $13 \pm 1^{\mathrm{c}}$ & $21 \pm 1^{b}$ & $24 \pm 2^{a}$ & $12 \pm 1^{\mathrm{c}}$ & $<0.001$ \\
\hline 10 & 18.79 & 354 & 463 & $301(100)$ & Quercetin-3-O-glucoside & $13 \pm 1^{b}$ & nd & $24 \pm 3^{a}$ & $13 \pm 1^{b}$ & $<0.001$ \\
\hline 11 & 19.14 & 353 & 463 & $301(100)$ & Quercetin-O-hexoside II & $13 \pm 1^{b}$ & nd & $24 \pm 1^{\mathrm{a}}$ & $12 \pm 1^{b}$ & $<0.001$ \\
\hline 12 & 19.70 & 285 & 567 & $273(100)$ & Phloretin-2-O-xyloglucoside & $20 \pm 4^{a}$ & $\operatorname{tr}$ & $15 \pm 1^{b}$ & $11 \pm 1^{c}$ & $<0.001$ \\
\hline 14 & 22.27 & 350 & 623 & $315(100)$ & Isorhamnetin-3-O-rutinoside & $12 \pm 1^{\mathrm{c}}$ & $20 \pm 1^{b}$ & $24 \pm 2^{\mathrm{a}}$ & $12 \pm 1^{\mathrm{c}}$ & $<0.001$ \\
\hline \multirow[t]{2}{*}{15} & 22.89 & 285 & 435 & $273(100)$ & $\begin{array}{c}\text { Phlorizin } \\
\text { (phloretin-2-O-glucoside) }\end{array}$ & $24 \pm 1^{b}$ & $\operatorname{tr}$ & $39 \pm 1^{a}$ & $9 \pm 1^{c}$ & $<0.001$ \\
\hline & & & & & Phenolic compounds & $301 \pm 32^{b}$ & $182 \pm 7^{c}$ & $375 \pm 42^{a}$ & $197 \pm 5^{c}$ & $<0.001$ \\
\hline
\end{tabular}

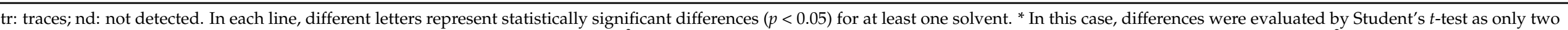

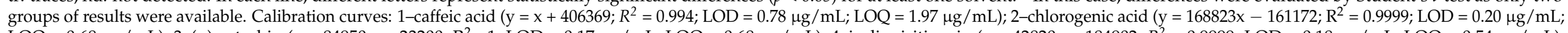

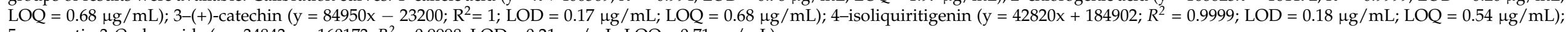
5-quercetin 3-O-glucoside ( $\left.\mathrm{y}=34843 \mathrm{x}-160173 ; R^{2}=0.9998 ; \mathrm{LOD}=0.21 \mu \mathrm{g} / \mathrm{mL} ; \mathrm{LOQ}=0.71 \mu \mathrm{g} / \mathrm{mL}\right)$. 


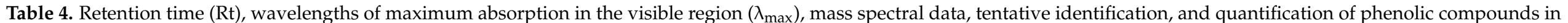
apple pomace from Tuinsappen Lombarts Calville (Belgium).

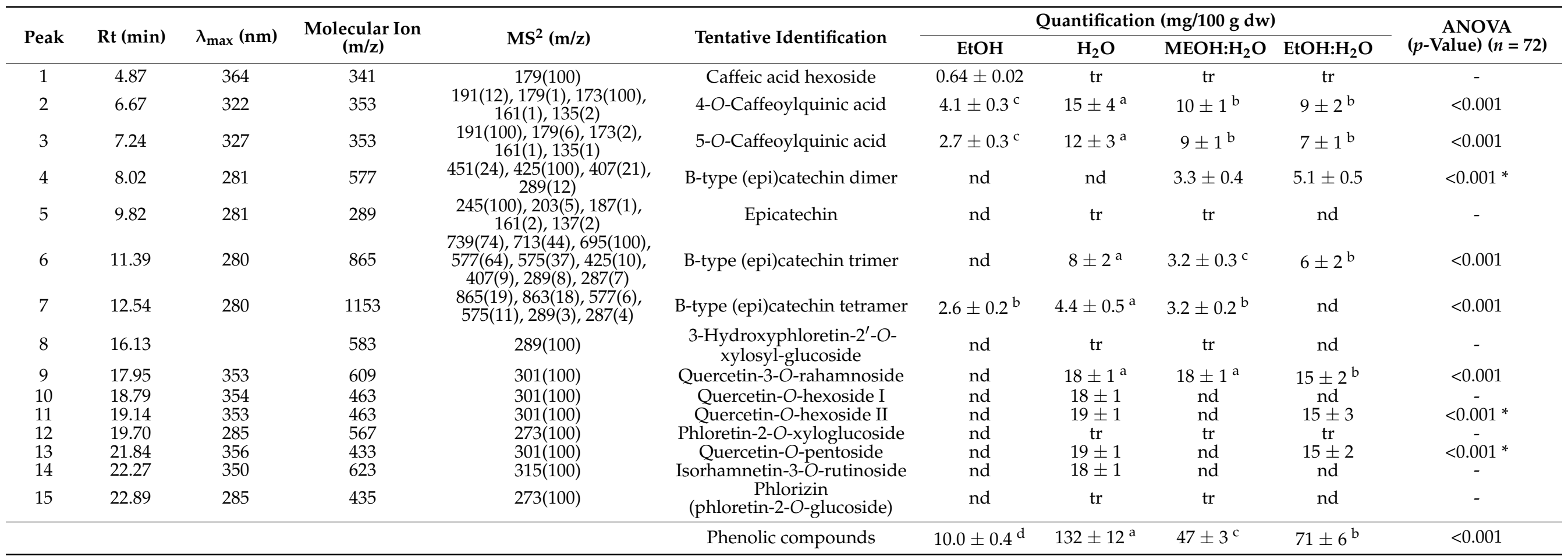

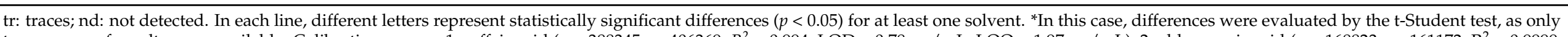

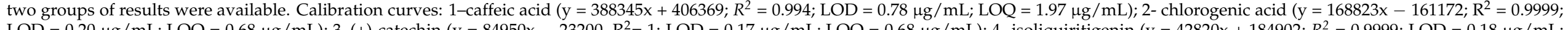

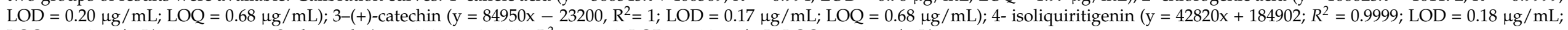
$\mathrm{LOQ}=0.54 \mu \mathrm{g} / \mathrm{mL}) ; 5$-quercetin 3-O-glucoside $\left(\mathrm{y}=34843 \mathrm{x}-160173 ; R^{2}=0.9998 ; \mathrm{LOD}=0.21 \mu \mathrm{g} / \mathrm{mL} ; \mathrm{LOQ}=0.71 \mu \mathrm{g} / \mathrm{mL}\right)$. 
As for the Belgian apple pomace samples that remained after cider production (Table 4), the same phenolic compound profile could only be noticed in aqueous extracts. The compounds referring to peaks 4-6 and 8-15 were not present in ethanolic extracts; 10, 11, 13, and 14 were absent from $\mathrm{MeOH}: \mathrm{H}_{2} \mathrm{O}$ extracts; and $\mathrm{EtOH}: \mathrm{H}_{2} \mathrm{O}$ extracts did not present compounds referring to peaks $5,7,8,10,14$, and 15 . In the case of apple pomace samples from juice extraction, the results were even worse, since the chromatograms obtained from the corresponding extracts did not reveal any peaks.

In addition to their higher diversity, the extracts obtained from the Spanish apple pomace also presented the highest concentration of phenolic compounds, as was particularly obvious for $\mathrm{EtOH}(301 \mathrm{mg} / 100 \mathrm{~g} \mathrm{dw}), \mathrm{MeOH}: \mathrm{H}_{2} \mathrm{O}$ (375 mg/100 g dw), and EtOH: $\mathrm{H}_{2} \mathrm{O}$ $(197 \mathrm{mg} / 100 \mathrm{~g} \mathrm{dw})$ extracts. It should be remembered that apple pomace samples provided by the Spanish company were lyophilized for subsequent analysis, while the Belgian ones were subjected to thermal drying, which may be the basis of the poor results attained for the latter samples. Furthermore, the major compound found in the Spanish apple pomace extract was 5-O-caffeoylquinic acid, with concentrations between 66 and $114 \mathrm{mg} / 100 \mathrm{~g} \mathrm{dw}$ for hydroethanolic and ethanolic extracts, respectively. However, owing to their validated cosmetic advantages linked with skin health [28], and in view of the main purpose of this work, the di-hydrochalcones (3-hydroxyphloretin-2'-O-xylosyl-glucoside, phloretin2-O-xyloglucoside, and phloretin-2-O-glucoside) should also be considered. Given the presented results, it seems reasonable to indicate lyophilization as the method of choice for the pretreatment of apple pomace, as samples subjected to this drying process presented a greater number and amount of different phenolic compounds, increasing its interest for potential incorporation in dermocosmetic formulations.

\subsection{Bioactive Properties}

\subsubsection{Antioxidant Activity}

The results obtained for antioxidant activity of the studied apple pomace extracts are presented in Table 5. Among the three studied samples extracted with different solvents, the hydromethanolic and hydroethanolic extracts from the Spanish apple pomace samples showed the highest antioxidant activity with the lowest $\mathrm{EC}_{50}$ values in all assays except for the $\beta$-carotene bleaching inhibition, for which the ethanolic extract proved to be more effective. These results were somehow predictable given the phenolic profile presented by the Spanish apple pomace hydromethanolic extract, which presented the greatest amount of total phenolics compared to the other studied extracts. However, when comparing different solvents, it was also evident that the antioxidant activity measured in the Spanish apple pomace extracts was provided by compounds other than phenolic compounds, as there is no direct correlation among the concentration of phenolic compounds (Table 3 ) and the $\mathrm{EC}_{50}$ values obtained in each assay.

Considering the lipid composition of human skin, the ethanolic extracts could be considered as the best choice, thus being selected for the antimicrobial activity assay described in the next section. Owing to their innocuous nature, the hydroethanolic extracts were also tested. 
Table 5. Antioxidant activity of the studied apple pomace samples $\left(\mathrm{EC}_{50}, \mu \mathrm{g} / \mathrm{mL}\right.$; mean $\left.\pm \mathrm{SD}\right)$.

\begin{tabular}{|c|c|c|c|c|}
\hline \multicolumn{5}{|c|}{ DPPH Scavenging Activity } \\
\hline & EtOH & $\mathrm{H}_{2} \mathrm{O}$ & $\mathrm{MeOH}: \mathrm{H}_{2} \mathrm{O}(80: 20)$ & EtOH: $\mathrm{H}_{2} \mathrm{O}(80: 20)$ \\
\hline Spanish & $4.1 \pm 0.4$ & $1.7 \pm 0.2$ & $0.6 \pm 0.1$ & $0.7 \pm 0.1^{\mathrm{c}}$ \\
\hline Belgian (cider) & $>10$ & $9 \pm 1$ & $>10$ & $10 \pm 1^{\mathrm{a}}$ \\
\hline Belgian (juice) & $>10$ & $>10$ & $>10$ & $9 \pm 1^{b}$ \\
\hline $\begin{array}{l}\text { ANOVA or Student's } t \text {-test } \\
(p \text {-value })(n=54)\end{array}$ & - & $<0.001$ & - & $<0.001$ \\
\hline \multicolumn{5}{|c|}{ Reducing Power } \\
\hline & EtOH & $\mathrm{H}_{2} \mathrm{O}$ & $\mathrm{MeOH}: \mathrm{H}_{2} \mathrm{O}(80: 20)$ & EtOH: $\mathrm{H}_{2} \mathrm{O}(80: 20)$ \\
\hline Spanish & $1.0 \pm 0.1$ & $1.0 \pm 0.1$ & $0.35 \pm 0.02$ & $0.62 \pm 0.02^{c}$ \\
\hline Belgian (cider) & $>10$ & $4.2 \pm 0.5$ & $>10$ & $5.2 \pm 0.3^{\mathrm{a}}$ \\
\hline Belgian (juice) & $>10$ & $>10$ & $>10$ & $2.5 \pm 0.1^{b}$ \\
\hline $\begin{array}{l}\text { ANOVA or Student's } t \text {-test } \\
\quad(p \text {-value })(n=54)\end{array}$ & - & $<0.001$ & - & $<0.001$ \\
\hline \multicolumn{5}{|c|}{$\beta$-Carotene Bleaching Inhibition } \\
\hline & EtOH & $\mathrm{H}_{2} \mathrm{O}$ & MeOH: $\mathrm{H}_{2} \mathrm{O}(80: 20)$ & EtOH: $\mathrm{H}_{2} \mathrm{O}(80: 20)$ \\
\hline Spanish & $0.8 \pm 0.1$ & $3.4 \pm 0.3$ & $1.4 \pm 0.2$ & $1.2 \pm 0.3$ \\
\hline Belgian (cider) & $>10$ & $>10$ & $>10$ & $>10$ \\
\hline Belgian (juice) & $>10$ & $>10$ & $>10$ & $>10$ \\
\hline $\begin{array}{c}\text { ANOVA } \\
(p \text {-value })(n=54)\end{array}$ & - & - & - & - \\
\hline
\end{tabular}

Results of the antioxidant activity are expressed in $\mathrm{EC}_{50}$ values: sample concentration providing $50 \%$ of the antioxidant activity or 0.5 of absorbance in the reducing power. Uppercase letters indicate statistically significant differences among each pomace type (different classifications for each antioxidant assay).

\subsubsection{Antimicrobial Activity}

The antimicrobial activity of the selected ethanolic and hydroethanolic extracts from the Spanish apple pomace samples was measured against $P$. acnes, owing to their relevance in the acne process; methicillin-resistant Staphylococcus aureus (MRSA); Proteus mirabilis, and Pseudomonas aeruginosa, and the results are presented in Table 6. The minimal inhibitory concentration (MIC) values were not exceptionally low, but in the specific case of $P$. acnes, the results attained for the hydromethanolic extract $(0.5 \mathrm{mg} / \mathrm{mL})$ might be considered satisfactory.

Table 6. Antimicrobial activity of the selected apple pomace ethanolic and hydroethanolic extracts from Corporación Hijos de la Rivera S.L. (Spain).

\begin{tabular}{ccc}
\hline & EtOH Extract & EtOH: $\mathbf{H}_{\mathbf{2}} \mathbf{O}$ Extract \\
\hline Bacteria & MIC $(\mathbf{m g} / \mathbf{m L})$ & MIC $(\mathbf{m g} / \mathbf{m L})$ \\
\hline Propionibacterium acnes & 5 & 2.5 \\
MRSA & 5 & 2.5 \\
Proteus mirabilis & 20 & 10 \\
Pseudomonas aeruginosa & $>20$ & $>20$ \\
\hline
\end{tabular}

Minimum inhibitory concentration (MIC); methicillin-resistant Staphylococcus aureus (MRSA).

\subsection{Dermocosmetic Gel Formulation and Characterization}

In order to obtain a formulation free of artificial ingredients as much as possible, pectin extracted from the apple pomace samples was employed as a gelling agent. This methodology was conducted in our lab for the first time, being especially optimized for the current work. Thus, different $\mathrm{pH}$ conditions were assayed, allowing to achieve 
pectin extraction yields varying from 1.69 up to $1.87 \%$ to be further incorporated in the formulated hydrogel.

Regarding the antimicrobial results, the hydroethanolic extract was chosen to be incorporated in the hydrogel $(5 \mathrm{mg} / \mathrm{mL})$, which was subsequently tested for its antioxidant and antimicrobial activity.

In terms of antioxidant activity, a DPPH scavenging effect of over $85 \%$ was achieved in the hydrogel formulation, while the absorbance of the reaction endpoint in the reducing power assay was 1.858 , a value much higher than the established $\mathrm{EC}_{50}$ value $(0.500)$.

Regarding antimicrobial activity, the formulated hydrogel was tested only against $P$. acnes as this species was the most relevant considering the purpose of this work. However, the bacterial growth was not inhibited, probably due to the $2 \times$ dilution effect induced by the solubilization of the gel in culture medium. Therefore, a second gel was prepared with $10 \mathrm{mg} / \mathrm{mL}$ of hydroethanolic extract. In this second attempt, the growth of P. acnes was effectively inhibited.

\section{Conclusions}

Considering the main goal of the present study, it can be concluded that the selected drying method has a high influence over the phenolic profile, since the lyophilized samples presented a higher diversity and concentration of these compounds. Additionally, it was also verified that the chosen solvent has a considerable effect with different outcomes among thermally dried or freeze-dried samples; in fact, in the case of Spanish samples, methanol:water (375 mg/100 g dw) and ethanol (301 mg/100 g dw) led to the highest yields, while the corresponding result was obtained with water $(132 \mathrm{mg} / 100 \mathrm{~g} \mathrm{dw})$ and the water:ethanol mixture $(71 \mathrm{mg} / 100 \mathrm{~g} \mathrm{dw})$ in the case of Belgian samples.

Taking the former results into account, and considering the lipid composition of human skin, the hydroethanolic extract was chosen to be added to the hydrogel as it is also much less toxic than methanol.

Regarding the bioactivity of the extracts, the hydroethanolic extract presented good antibacterial activity against $P$. acnes (MIC $=2.5 \mathrm{mg} / \mathrm{mL}$ ), MRSA (MIC $=2.5 \mathrm{mg} / \mathrm{mL}$ ), and Proteus mirabilis (MIC $=10 \mathrm{mg} / \mathrm{mL}$ ); the result obtained for P. acnes is especially important, as this bacterium is associated with skin disorders, such as acne.

For the dermal hydrogel formulation, pectin was obtained by hot acid extraction; however, this method, at an industrial scale, produces pectin with a lower degree of polymerization and produces high amounts of chemical waste. Therefore, the study of possible alternative methods, such as enzymatic extraction, would be interesting for future research in this field. The resulting hydrogel was shown to have antioxidant and antimicrobial activity against $P$. acnes at a concentration of $5 \mathrm{mg} / \mathrm{mL}$, thus validating its application as a cosmeceutical.

In general, apple pomace proved to be a valuable source of bioactive compounds, especially polyphenols and pectin, which could be applied in dermal formulations. The apple pomace phenolics proved not only its antioxidant activity but also its antimicrobial potential against skin bacteria. However, further research would be needed in this field to confirm the anti-acne potential of apple pomace polyphenols.

Thus, it is evident that, using a circular economy approach, industrial by-products which are typically discarded as waste, could have interesting applications to obtain highvalue compounds that are likely to be used in different industrial sectors, such as food, cosmetic, and pharmaceutical applications.

Author Contributions: Conceptualization, J.C.M.B.; methodology, A.A.A., Â.L. and M.J.A.; validation, I.C.F.R.F. and L.B.; writing-original draft preparation, M.I.D., A.A.A. and Â.L.; writing-review and editing, J.C.M.B. and L.B.; supervision, J.C.M.B. and I.C.F.R.F. All authors have read and agreed to the published version of the manuscript.

Funding: This research was funded by Foundation for Science and Technology (FCT, Portugal) through national funds to CIMO (UIDB/00690/2020), the institutional scientific employment pro- 
gram contract for L. Barros and M.I. Dias and through the individual scientific employment program contract for J. Barreira. Research was also funded by the FEDER Interreg España-Portugal program through the project TRANSCOLAB 0612_TRANS_CO_LAB_2_P and by the ERDF through the Regional Operational Program North 2020, within the scope of project Mobilizador Norte-01-0247FEDER-024479: ValorNatural ${ }^{\circledR}$ and Project GreenHealth-Norte-01-0145-FEDER-000042.

Conflicts of Interest: The authors declare no conflict of interest.

\section{References}

1. Dorni, A.C.; Amalraj, A.; Gopi, S.; Varma, K.; Anjana, S. Novel cosmeceuticals from plants-An industry guided review. J. Appl. Res. Med. Aromat. Plants 2017, 7, 1-26. [CrossRef]

2. Bandoni, A.; Ferraro, G.; Martino, V.; Naidic, J. Fitocosmética: Fitoingredientes y Otros Productos Naturales; EUDEBA: Buenos Aires, Argentina, 2012.

3. Joshi, L.S.; Pawar, H.A. Herbal Cosmetics and Cosmeceuticals: An Overview. Nat. Prod. Chem. Res. 2015, 3. [CrossRef]

4. ProFound, J.; Duerbeck, K. The market for natural ingredients for cosmetics in the EU. CBI Mark. Surv. 2008. Available online: https:/ / www.yumpu.com/en/ document/view/3702647/the-market-for-natural-ingredients-for-cosmetics-in-the-eu (accessed on 1 June 2018).

5. Chow, E.T.; Mahalingaiah, S. Cosmetics use and age at menopause: Is there a connection? Fertil. Steril. 2016, 106, 978-990. [CrossRef]

6. Mukherjee, P.K.; Maity, N.; Nema, N.K.; Sarkar, B.K. Bioactive compounds from natural resources against skin aging. Phytomedicine 2011, 19, 64-73. [CrossRef]

7. Gullón, B.; Falqué, E.; Alonso, J.L.; Parajó, J.C. Evaluation of apple pomace as a raw material for alternative applications in food industries. Food Technol. Biotechnol. 2007, 45, 426-433.

8. Bhushan, S.; Kalia, K.; Sharma, M.; Singh, B.; Ahuja, P.S. Processing of Apple Pomace for Bioactive Molecules. Crit. Rev. Biotechnol. 2008, 28, 285-296. [CrossRef]

9. Waldbauer, K.; McKinnon, R.; Kopp, B. Apple Pomace as Potential Source of Natural Active Compounds. Planta Medica 2017, 83, 994-1010. [CrossRef] [PubMed]

10. Barbulova, A.; Colucci, G.; Apone, F. New Trends in Cosmetics: By-Products of Plant Origin and Their Potential Use as Cosmetic Active Ingredients. Cosmetics 2015, 2, 82-92. [CrossRef]

11. Klemetsrud, T.; Jonassen, H.; Hiorth, M.; Kjøniksen, A.-L.; Smistad, G. Studies on pectin-coated liposomes and their interaction with mucin. Colloids Surf. B Biointerfaces 2013, 103, 158-165. [CrossRef] [PubMed]

12. Naqash, F.; Masoodi, F.; Rather, S.A.; Wani, S.; Gani, A. Emerging concepts in the nutraceutical and functional properties of pectin-A Review. Carbohydr. Polym. 2017, 168, 227-239. [CrossRef]

13. Thakur, B.R.; Singh, R.K.; Handa, A.K.; Rao, M.A. Chemistry and uses of pectin-A review. Crit. Rev. Food Sci. Nutr. 1997, 37, 47-73. [CrossRef] [PubMed]

14. Krawitzky, M.; Arias, E.; Peiro, J.; Negueruela, A.; Val, J.; Oria, R. Determination of Color, Antioxidant Activity, and Phenolic Profile of Different Fruit Tissue of Spanish 'Verde Doncella' Apple Cultivar. Int. J. Food Prop. 2014, 17, 2298-2311. [CrossRef]

15. Zhang, T.; Wei, X.; Miao, Z.; Hassan, H.; Song, Y.; Fan, M. Screening for antioxidant and antibacterial activities of phenolics from Golden Delicious apple pomace. Chem. Central J. 2016, 10, 1-9. [CrossRef]

16. Park, E.K.; Ahn, S.R.; Kim, D.-H.; Lee, E.-W.; Kwon, H.J.; Kim, B.W.; Kim, T.H. Effects of unripe apple polyphenols on the expression of matrix metalloproteinase-1 and type-1 procollagen in ultraviolet irradiated human skin fibroblasts. J. Korean Soc. Appl. Biol. Chem. 2014, 57, 449-455. [CrossRef]

17. Lee, K.-E.; Youm, J.-K.; Lee, W.J.; Kang, S.; Kim, Y.J. Polyphenol-rich apple extract inhibits dexamethasone-induced sebaceous lipids production by regulating SREBP1 expression. Exp. Dermatol. 2017, 26, 958-960. [CrossRef]

18. Matsumoto, T.; Matsubara, Y.; Mizuhara, Y.; Sekiguchi, K.; Koseki, J.; Tsuchiya, K.; Nishimura, H.; Watanabe, J.; Kaneko, A.; Maemura, K.; et al. Plasma Pharmacokinetics of Polyphenols in a Traditional Japanese Medicine, Jumihaidokuto, Which Suppresses Propionibacterium acnes-Induced Dermatitis in Rats. Molecules 2015, 20, 18031-18046. [CrossRef]

19. Iyda, J.H.; Fernandes, R.C.; Calhelha, R.C.; Alves, M.J.; Ferreira, F.D.; Barros, L.; Amaral, J.S.; Ferreira, I.C. Nutritional composition and bioactivity of Umbilicus rupestris (Salisb.) Dandy: An underexploited edible wild plant. Food Chem. 2019, 295, 341-349. [CrossRef] [PubMed]

20. Barros, L.; Pereira, E.; Calhelha, R.C.; Dueñas, M.; Carvalho, A.M.; Santos-Buelga, C.; Ferreira, I. Bioactivity and chemical characterization in hydrophilic and lipophilic compounds of Chenopodium ambrosioides L. J. Funct. Foods 2013, 5, 1732-1740. [CrossRef]

21. AOAC. Official Methods of Analysis of AOAC International, 20th ed.; AOAC: Gaithersburg, MD, USA, 2016.

22. Bessada, S.; Barreira, J.; Barros, L.; Ferreira, I.C.; Oliveira, B. Phenolic profile and antioxidant activity of Coleostephus myconis (L.) Rchb.f.: An underexploited and highly disseminated species. Ind. Crop. Prod. 2016, 89, 45-51. [CrossRef]

23. Barreira, J.; Rodrigues, S.; Carvalho, A.M.; Ferreira, I. Development of hydrosoluble gels with Crataegus monogyna extracts for topical application: Evaluation of antioxidant activity of the final formulations. Ind. Crop. Prod. 2013, 42, 175-180. [CrossRef]

24. Miceli-Garcia, L.G. Pectin from apple pomace-Extraction, characterization, and utilization in encapsu-lating alpha-tocopherol acetate. Master Thesis, University of Nebraska-Lincoln, Lincoln, NE, USA, 2014. 
25. Featherstone, S. A Complete Course in Canning and Related Processes; Woodhead: Illinois, IL, USA, 2015. [CrossRef]

26. Madrera, R.R.; Bedriñana, R.P.; Valles, B.S. Enhancement of the nutritional properties of apple pomace by fermentation with autochthonous yeasts. LWT 2017, 79, 27-33. [CrossRef]

27. Clifford, M.N.; Knight, S.; Kuhnert, N. Discriminating between the Six Isomers of Dicaffeoylquinic Acid by LC-MSn. J. Agric. Food Chem. 2005, 53, 3821-3832. [CrossRef] [PubMed]

28. Casarini, T.P.A.; Frank, L.A.; Pohlmann, A.R.; Guterres, S.S. Dermatological applications of the flavonoid phloretin. Eur. J. Pharmacol. 2020, 889, 173593. [CrossRef] [PubMed] 